\title{
Mixotrophy in Fragilidium subglobosum (Dinophyceae): growth and grazing responses as functions of light intensity
}

\author{
Alf Skovgaard* \\ Marine Biological Laboratory, University of Copenhagen, Strandpromenaden 5, DK-3000, Helsinger, Denmark
}

\begin{abstract}
Growth and ingestion rates of the marine mixotrophic dinoflagellate Fragilidium subglobosum were studied as functions of light intensity with and without the presence of particulate food (Ceratium spp.). F. subglobosum was shown to be a facultative mixotroph; it was capable of phototrophic growth in monocultures as well as of heterotrophic (phagotrophic) growth in the dark. When F subglobosum was growing in light in food-satiated cultures, growth rates were higher than pure phototrophic growth rates at corresponding light intensities. At high light intensities, ingestion was inversely related to light intensity, but this did not apply to lower light intensities. Phagotrophy thus accounted for 34 to $100 \%$ of total growth in food-satiated cultures according to light intensity. Chlorophyll a content per cell of $F$. subglobosum decreased with increasing light intensity and ingestion of prey also resulted in a decreased chlorophyll a content. Phototrophic monocultures of $F$ subglobosum needed approximately $24 \mathrm{~h}$ following the addition of prey to fully adapt to phagotrophic metabolism.
\end{abstract}

KEY WORDS: Mixotrophy - Phagotrophy - Fragilidium subglobosum - Growth rate - Ingestion rate Chlorophyll a content - Ceratium spp.

\section{INTRODUCTION}

Mixotrophy (i.e. the simultaneous capability of phototrophy and heterotrophy) is widespread among certain protist taxa and in particular among flagellates such as chrysomonads, haptophytes and dinoflagellates (reviewed by Sanders \& Porter 1988). Several experimental studies have recently been reported dealing with the physiology of phagotrophic, mixotrophic flagellates (e.g. Andersson et al. 1989, Sanders et al. 1990, Caron et al. 1993, Jones et al. 1993) and these studies have revealed different nutritional strategies. Mixotrophy is obligatory in some species, i.e. both particulate food and light is needed for sustaining growth; this is probably due to the need for phagotrophically derived growth factors (Kimura \& Ishida 1985, 1989, Caron et al. 1993). Other species exhibit facultative mixotrophy, i.e. the ability to grow exclusively by

\footnotetext{
•E-mail: skovgaard@dk-online.dk
}

either phototrophy or phagotrophy (Andersson et al. 1989, Sanders et al. 1990, Holen \& Boraas 1995). Such species are thus beyond any doubt able to exploit ingested particles as an energy source. Furthermore some obligate phototrophic flagellates are facultatively phagotrophic (Veen 1991, Jones et al. 1993), implying that photosynthesis, but not phagotrophy, is essential for growth.

Although several dinoflagellates are assumed to be mixotrophic (Gaines \& Elbrächter 1987), the ecology of mixotrophic dinoflagellates has never been subject to thorough experimental studies. The present study treats the physiology of the thecate mixotrophic dinoflagellate Fragilidium subglobosum (v. Stosch) Loeblich, a mixotroph which apparently preys exclusively on species of another dinoflagellate genus, Ceratium (Skovgaard in press). Unusually for a thecate dinoflagellate, F. subglobosum phagocytizes its prey by direct engulfment, even though the prey may be up to 2 times its own size (Skovgaard in press). This study focuses on the relative importance of phototrophy and phagotro- 
phy for the nutrition of F. subglobosum grown in laboratory cultures and on the ability to 'switch' between these 2 nutritional modes.

\section{MATERIALS AND METHODS}

Fragilidium subglobosum was isolated from a $20 \mu \mathrm{m}$ net-sample collected in the Kattegat (Denmark) in autumn 1993. The phototrophic dinoflagellate prey Ceratium lineatum (Ehrenberg) Cleve and $C$. tripos (Müller) Nitzsch were obtained from the culture collection of the Marine Biological Laboratory, Helsingør, Denmark. The organisms were grown in B-medium (Hansen 1989) based on seawater (28\% salinity) at $15 \pm 0.5^{\circ} \mathrm{C}$ following a $16 \mathrm{~h}$ light $8 \mathrm{~h}$ dark cycle. Experiments were carried out in $270 \mathrm{ml}$ polystyrene bottles allowing light to penetrate from only 1 direction. The experimental bottles were mounted on a vertical rotating plankton-wheel (1 rpm) in a water-cooled incubator. Light was adjusted by varying the distance between the incubator and the light source (cool white fluorescent tubes) in combination with attenuation by Letratone $^{\otimes}$ screening film (Letraset, England). Light intensity (photosynthetically active radiation, 400 to $700 \mathrm{~nm}$ ) was measured inside an experimental bottle using a LI-COR LI-1000 (LI-COR, USA) radiation sensor equipped with a flat LI-192SA underwater quantum sensor.

Determination of growth and grazing rates. Both Fragilidium subglobosum and prey cells were allowed to acclimate to the appropriate light intensity for 4 to $5 \mathrm{~d}$ prior to all experiments. In order to determine growth rates of $F$. subglobosum, samples were fixed in Lugol's solution and $>400$ cells were counted at intervals of $\geq 24 \mathrm{~h}$ using an inverted microscope. Population growth rate of $F$. subglobosum, $\mu_{Y}$, was calculated from:

$$
Y\left(t_{1}\right)=Y\left(t_{0}\right) \mathrm{e}^{\mu_{Y}\left(t_{1}-t_{0}\right)}
$$

where $Y\left(t_{0}\right)$ and $Y\left(t_{1}\right)$ denote the cell concentration at the start $\left(t_{0}\right)$ and at the end $\left(t_{1}\right)$ of the incubation period, respectively, assuming exponential growth.

Ingestion rate, $U$, in food-satiated cultures was determined from the reduction in prey, $X$, concentrations as compared with control bottles without predators ( $>400$ cells counted). The prey in the experimental bottles as well as in the control bottles was assumed to grow exponentially according to

$$
X_{c}\left(t_{1}\right)=X_{c}\left(t_{0}\right) \mathrm{e}^{\mu_{x}\left(t_{1}-t_{0}\right)}
$$

where $\mu_{X}$ is the growth rate of the prey in control bottles with cell concentrations $X_{c}\left(t_{0}\right)$ and $X_{c}\left(t_{1}\right)$ at the beginning and at the end of the incubation period, respectively. Tizus

$$
\frac{\mathrm{d} X}{\mathrm{~d} t}=\mu_{X} X-U Y
$$

and

$$
\frac{\mathrm{d} Y}{\mathrm{~d} t}=\mu_{Y} Y
$$

where the prey, $X$, is ingested by the predator, $Y$, at the per capita ingestion rate, $U$ (dimension: $X Y^{-1} t^{-1}$ ). $U Y$ (dimension: $X t^{-1}$ ) is thus the mortality of prey due to grazing. The equations are valid only if $U$ and $\mu_{Y}$ are independent of the prey concentration, $X$, which in the present experiments is assumed to be the case because the prey concentrations were kept far above the saturation concentration. Having determined $X\left(t_{0}\right), X\left(t_{1}\right)$, $Y\left(t_{0}\right), Y\left(t_{1}\right), \mu_{X}$ and $\mu_{Y}, U$ could be calculated iteratively from Eqs. (1) \& (2) usinç a simple computer model.

Ceratium lineatum was used as food at a concentration of approximately 800 cells $\mathrm{ml}^{-1}$ in all experiments designed for determination of growth and ingestion rates; samples were withdrawn approximately every $24 \mathrm{~h}$ in order to obtain a significant decrease in prey densities (10 to $20 \%$ ). This prey concentration was shown to be at least 4 times the saturation concentration (data not shown). The predator:prey concentration ratio was approximately $1: 10$. If necessary, predator and prey densities were adjusted before each $24 \mathrm{~h}$ incubation period by dilution of the predator and/or by adding prey grown in experimental light conditions. Cell volumes of Fragilidium subglobosum were estimated at the end of each experiment from the linear dimension of Lugol-fixed cells assuming a spherical shape. Volumes of Ceratium spp. were estimated in a similar way, using a combination of simple geometric shapes (1 hemisphere and 3 cones). The volumes of Ceratium spp. were calculated as the means of 100 cells measured per prey species.

Phototrophic growth. Phototrophic growth of Fragilidium subglobosum in monocultures (absence of prey) was measured at light intensities ranging from darkness to $395 \mu \mathrm{E} \mathrm{m}^{-2} \mathrm{~s}^{-1}$ (Fig. 1). Four acclimated cultures were inoculated at each light intensity and samples were taken every 2 to $5 \mathrm{~d}$ for up to $2 \mathrm{wk}$. The light compensation point, $l\left(\mu_{0}\right)$, was defined as the lowest light intensity which supported growth. The saturating light intensity, $I\left(\mu_{\max }\right)$, was defined as the lowest light intensity which supported maximum growth.

Mixotrophic growth. Growth and ingestion rates of Fragilidium subglobosum growing in mixotrophic cultures (i.e. cultures fed Ceratium lineatum) were determined at a variety of light intensities. The light intensities were approximately the same as for phototrophic growth (Fig. 1). Following the light-acclimation period, $4 F$ subglobosum cultures were fed and incubated for additional $3 \mathrm{~d}$ before the assay was started. The cultures were thereafter sampled every $24 \mathrm{~h}$ for 2 to $3 \mathrm{~d}$. Growth and ingestion were also studied in the dark in 
food-satiated cultures which had previously been growing for $>3 \mathrm{~d}$ in the dark. Every $24 \mathrm{~h}$, growth and grazing rates were determined and $C$. lineatum grown at $50 \mu \mathrm{E} \mathrm{m} \mathrm{m}^{-2} \mathrm{~s}^{-1}$ was added to keep satiated concentrations of viable prey. Phagotrophic yield in dark-grown cultures was estimated as volume increment of $F$. subglobosum per volume of ingested prey.

Chlorophyll a (chl a) content. Phototrophic monocultures of Fragilidium subglobosum and mixotrophic cultures fed Ceratium tripos were grown in triplicates at 3 different light intensities and in the dark. The light intensities of 10,107 and $160 \mu \mathrm{E} \mathrm{m}^{-2} \mathrm{~s}^{-1}$ were chosen since during the previous experiment these light intensities showed the ability to support different growth and ingestion rates. The cells were then retained on Whatman GF/C filters, extracted in ethanol, and chl a was measured spectrophotometrically (Lorenzen 1967). Mixotrophic cultures were starved before the chlorophyll a content was measured; i.e. all prey cells had been ingested $<24$ h prior to the measurements (controlled by use of a stereomicroscope).

Shift from phototrophic growth in light to phagotrophic growth in darkness. Growth and ingestion rates during the transition from phototrophy to phagotrophy were followed for $7 \mathrm{~d}$. Four phototrophically growing Fragilidium subglobosum cultures were acclimated in the light $\left(50 \mu \mathrm{E} \mathrm{m}^{-2} \mathrm{~s}^{-1}\right)$, after which Ceratium lineatum was added and the culture vessels were transferred to darkness. Every $24 \mathrm{~h}$ growth and grazing rates were determined and $C$. lineatum grown at $50 \mu \mathrm{E} \mathrm{m}^{-2} \mathrm{~s}^{-1}$ was added to keep satiated concentrations of viable prey.

Measurements of food uptake were also taken during the initiation of phagotrophy following pure phototrophic growth. Ceratium tripos (final conc. $\approx 200$ cells $\mathrm{ml}^{-1}$ ) was added to triplicate monocultures of phototrophically grown Fragilidium subglobosum ( $\sim 50$ cells $\mathrm{ml}^{-1}$ ), after which the cultures were transferred to darkness. Samples were taken periodically during a $21 \mathrm{~h}$ period, fixed in glutaraldehyde (final conc. $=1 \%$ ) and the proportions of $F$. subglobosum cells attached to prey cells or containing food vacuoles were enumerated (>600 F. subglobosum cells counted). A similar experiment was carried out using cultures of mixotrophically grown F. subglobosum cells. These cultures were grown in the light with $C$. tripos for $>5 \mathrm{~d}$ and were starved prior to the experiment. The large prey species C. tripos was used in these experiments because it facilitated distinction between small, partly digested food vacuoles and large, newly formed ones.

Shift from phototrophic growth to mixotrophic growth in light. The transition from phototrophy to mixotrophy was examined as above. A set of 4 replicates was treated as in the phototrophy-to-phagotrophy experiment, except the experiment, as well as the acclimation, was carried out in the light $\left(117 \mu \mathrm{E} \mathrm{m}^{-2} \mathrm{~s}^{-1}\right)$.

\section{RESULTS}

\section{Phototrophic growth}

Above $I\left(\mu_{0}\right)=7 \mu \mathrm{E} \mathrm{m}^{-2} \mathrm{~s}^{-1}$, pure phototrophic growth of Fragilidium subglobosum increased as a function of light intensity (Fig 1) reaching a maximum growth rate of $0.31 \mathrm{~d}^{-1}(\mathrm{SE}=0.02)$ at $I\left(\mu_{\max }\right)=$ $130 \mu \mathrm{E} \mathrm{m} \mathrm{m}^{-2} \mathrm{~s}^{-1}$. Above this light intensity growth

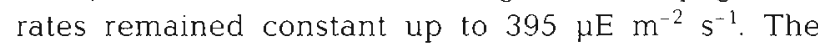
mean diameter of $F$. subglobosum cells growing in phototrophic monocultures was approximately $50 \mu \mathrm{m}$

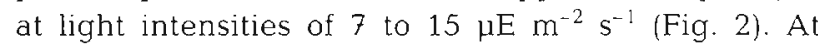
higher light intensities, mean diameter decreased to about $40 \mu \mathrm{m}$ corresponding to a decrease in volume from 65400 to $33500 \mu^{3}$. After $9 \mathrm{~d}$ in darkness, mean diameter had decreased to $35 \mu \mathrm{m}$. Mean volume of Ceratium lineatum was $8200 \mu^{3}$ and mean volume of $C$. tripos was $110000 \mu^{3}$.

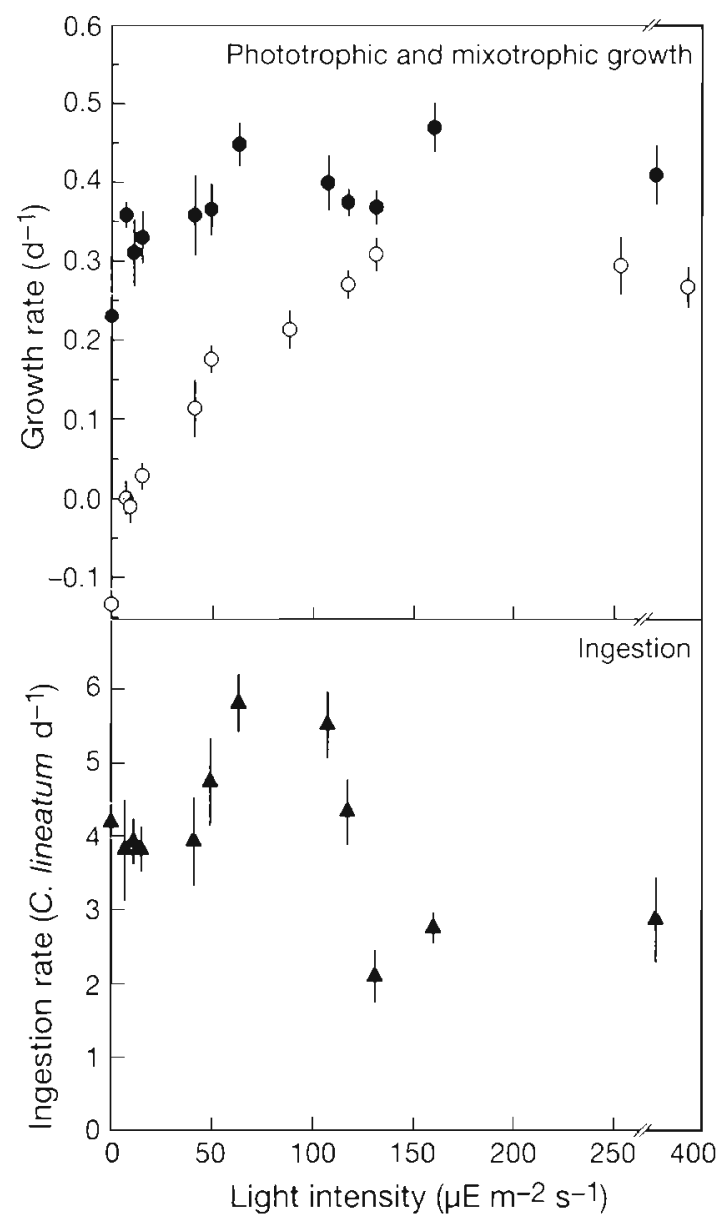

Fig. 1. Effect of light intensity on phototrophic growth rate of Fragilidium subglobosum in monocultures $(0)$ and on mixotrophic growth rate ( $\bullet$ ) and per capita ingestion rate (4) of $F$. subglobosum in food-satiated cultures ( 800 Ceratium lineatum $\left.\mathrm{ml}^{-1}\right)$. Error bars indicate $\pm 1 \mathrm{SE}, \mathrm{n}=4$ 


\section{Mixotrophic growth}

Growth rates of Fragilidium subglobosum in mixotrophic food-satiated cultures (Fig. 1) were less variable as a function of light intensity and were higher than growth rates in purely phototrophic monocultures. In food-satiated cultures, growth rates thus ranged from $0.31 \mathrm{~d}^{-1}(\mathrm{SE}=0.04)$ at $11 \mu \mathrm{E} \mathrm{m} \mathrm{m}^{-2} \mathrm{~s}^{-1}$ to $0.47 \mathrm{~d}^{-1}\left(\mathrm{SE}=0.03\right.$ ) at $160 \mu \mathrm{E} \mathrm{m} \mathrm{m}^{-2} \mathrm{~s}^{-1}$. The volume of $F$ subglobosum cells in mixotrophic cultures was $\sim 58000 \mu^{3}$ and was not affected by light intensity (Fig. 2). Per capita ingestion rates varied according to light intensity, ranging from 2.1 (SE $=0.3$ ) to 5.8 $(\mathrm{SE}=0.4)$ Ceratium lineatum $\mathrm{d}^{-1}$ (Fig. 1). Between the light intensities of $63 \mu \mathrm{E} \mathrm{m} \mathrm{m}^{-2} \mathrm{~s}^{-1}$, which was associated with maximum ingestion rate, and $I\left(\mu_{\max }\right)$, at which ingestion rate took a minimum value, ingestion was inversely related to light intensity. Above $I\left(\mu_{\max }\right)$ ingestion rates did not decrease any further. Below $63 \mu \mathrm{E}$ $\mathrm{m}^{-2} \mathrm{~s}^{-1}$, however, ingestion rates decreased to intermediate values $\left(\sim 4 \mathrm{C}\right.$. lineatum $\left.\mathrm{d}^{-1}\right)$. Pure phagotrophic growth in darkness was $0.23 \mathrm{~d}^{-1}(\mathrm{SE}=0.03)$, ingestion rate was $4.2 C$. lineatum $\mathrm{d}^{-1}(\mathrm{SE}=0.2)$ and phagotrophic yield in food-satiated dark-grown cultures was $41 \%$.

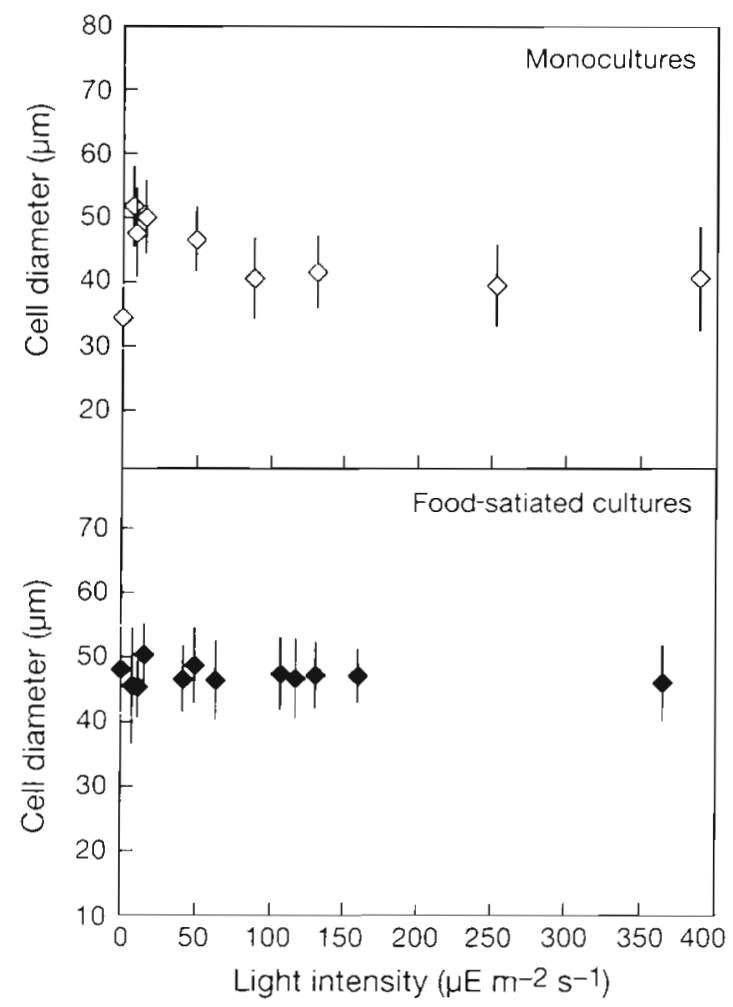

Fig. 2. Effect of light intensity on cell size (diameter) of Fragilidium subglobosum grown phototrophically in monocultures (above) and mixotrophically in food-satiated cultures with $\sim 800$ Ceratium lineatum $\mathrm{ml}^{-1}$ (below). Error bars indicate $\pm 1 \mathrm{SD}, \mathrm{n}=50$

\section{Chl a content}

The chl a content of Fragilidium subglobosum cells in phototrophic monocultures decreased as a function

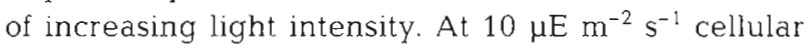
chl a content was $261 \mathrm{pg}$ cell ${ }^{-1}$; at $160 \mu \mathrm{E} \mathrm{m} \mathrm{m}^{-2} \mathrm{~s}^{-1}$, this was reduced by $71 \%$ (Fig. 3). The chl a content of cells growing mixotrophically in food-satiated cultures was generally lower. At $10 \mu \mathrm{E} \mathrm{m} \mathrm{m}^{-2} \mathrm{~s}^{-1}$, the chl a content of mixotrophically growing $F$ subglobosum cells was reduced by $49 \%$ in comparison to phototrophic monocultures. This reduction was only 10 to $26 \%$ at higher light intensities. After $9 \mathrm{~d}$ of phagotrophic growth in darkness, chl a content was 98 pg cell ${ }^{-1}$.

\section{Shift from phototrophic to phagotrophic growth}

When the basis for growth was changed from phototrophy only (light) to phagotrophy only (darkness + food), phototrophically based growth of Fragilidium subglobosum ceased after Day 1 (Fig. 4). Growth was thereafter based solely upon phagotrophy and phagotrophic growth appeared and reached a mean of $0.23 \mathrm{~d}^{-1}$ ( $\mathrm{SE}=0.03$ ) between Days 3 and 7 . The mean diameter of $F$. subglobosum cells was $48 \mu \mathrm{m}$ before as well as after the transition from phototrophy to phagotrophy (Fig. 2: size of cells growing at $50 \mu \mathrm{E}$ $\mathrm{m}^{-2} \mathrm{~s}^{-1}$ in monocultures vs cells growing in darkness in food-supplied cultures). The ingestion rate at Day 1 was low (2.1 Ceratium lineatum $\mathrm{d}^{-1}, \mathrm{SE}=0.2$ ), but from Day 2 the ingestion rates increased significantly (Fig. 4) reaching an overall mean of $4.2 \mathrm{C}$. lineatum $\mathrm{d}^{-1}(\mathrm{SE}=0.2)$.

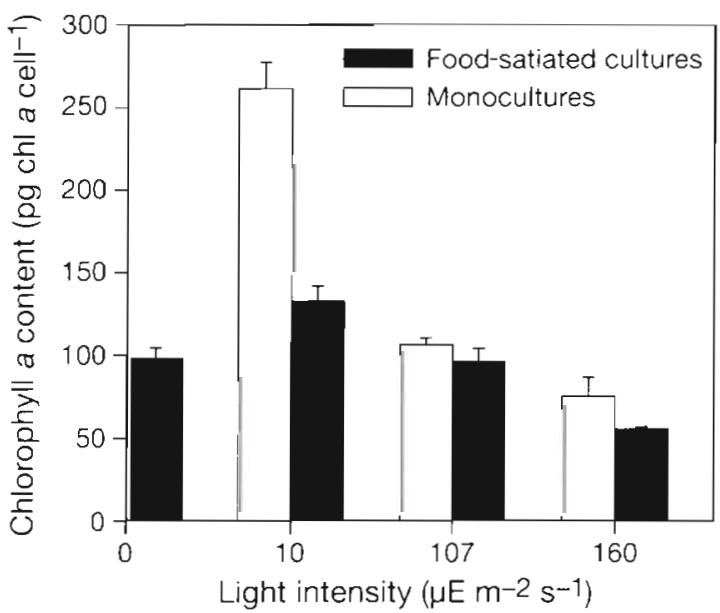

Fig. 3. Chl a content of Fragilidium subglobosum cells grown in phototrophic monocultures as well as in mixotrophic foodsatiated cultures at various light intensities. Error bars indicate $\pm 1 \mathrm{SE}, n=3$ 


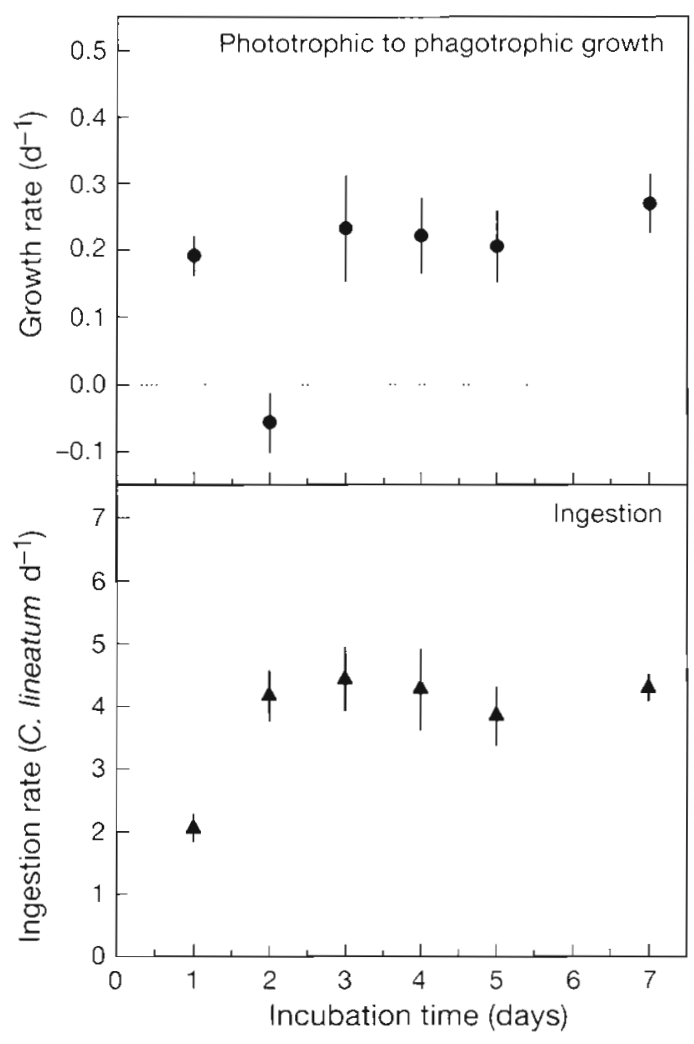

Fig. 4. Changes in phagotrophic growth rate (above) and per capita ingestion rate (below) of Fragilidium subglobosum fed with Ceratium lineatum $\left(\sim 800\right.$ cells $\left.\mathrm{ml}^{-1}\right)$. F. subglobosum was acclimated in phototrophic monocultures in the light, but transferred to darkness and fed at Day 0 . Error bars indicate $\pm 1 \mathrm{SE}, \mathrm{n}=4$

The percentage of Fragilidium subglobosum cells exhibiting phagotrophy (i.e attached to a prey cell or containing a food vacuole) was significantly affected by the nutritional mode of the cultures prior to experiments (Fig. 5). Phototrophically grown monocultures showed a slow response to the addition of prey. The fraction of $F$. subglobosum cells containing a food vacuole increased gradually reaching $50 \%$ after $21 \mathrm{~h}$ of incubation. The starved mixotrophically adapted cultures, on the other hand, responded rapidly to the addition of food; after $20 \mathrm{~min}, 48 \%$ of the population were attached to, or contained, a Ceratium tripos. After $1 \mathrm{~h}$ of incubation, the percentage of cells containing a food vacuole had increased to $67 \%$. The remaining $33 \%$ probably represent the proportion of the F. subglobosum population which at that time were at a stage where food uptake was not possible (i.e. division-cysts).

\section{Shift from phototrophic to mixotrophic growth}

When the basis for growth of Fragilidium subglobosum changed from phototrophy only (light) to mixo-

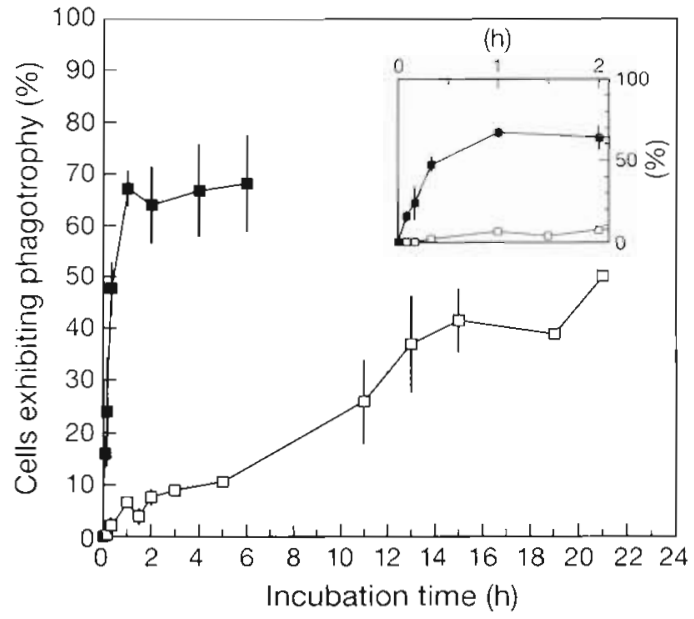

Fig. 5. Percentage of Fragilidium subglobosum populations exhibiting phagotrophy, i.e. attached to or containing a Ceratium tripos, as a function of incubation time. One set of cultures was grown in phototrophic monocultures prior to the experiment ( $\square$ ). The other set was grown in mixotrophic foodsatiated cultures (a) and starved prior to the experiment. Cultures were transferred to darkness and $C$. tripos was added at $t=0 \mathrm{~h}$. Inserted enlargement shows the first $2 \mathrm{~h}$ of the experiment. Error bars indicate $\pm 1 S E_{i} \mathrm{n}=3$

trophy (light + food), growth increased and reached an overall mean growth rate of $0.37 \mathrm{~d}^{-1}(\mathrm{SE}=0.02)$ from Day 3 onwards (Fig. 6). In contrast to the phototrophyto-phagotrophy experiment, light was available for photosynthesis during the entire experimental period and, therefore, photosynthetically based growth did not cease. Development of ingestion was similar to the phototrophy-to-phagotrophy experiment, i.e. it was low at Day 1 (1.2 Ceratium lineatum $\mathrm{d}^{-1}, \mathrm{SE}=0.7$ ), but increased at Day 2, reaching an overall mean of 4.6 C. Ineatum $\mathrm{d}^{-1}(\mathrm{SE}=0.4)$ between Days 2 and 5 .

\section{DISCUSSION}

This work represents the first experimental study on phototrophy and phagotrophy in a mixotrophic dinoflagellate, hence data must be compared to studies of purely phototrophic or heterotrophic dinoflagellates, or of mixotrophic flagellates belonging to other protist groups. Maximum phototrophic growth rate, $\mu_{\max }$ of Fragilidium subglobosum is, in general, fully comparable to volume-specific growth rates of phototrophic dinoflagellates (Banse 1982); just as $I\left(\mu_{0}\right)$ and $I\left(\mu_{\max }\right)$ of $F$ subglobosum are close to the mean values of the 16 phototrophic dinoflagellate species given by Richardson et al. (1983). Also, the heterotrophic capabilities of $F$, subglobosum (i.e. purely phagotrophic $\mu_{\max }$ and ingestion rate) are comparable to heterotrophic dinoflagellates in general (Hansen et al. unpubl.). On the 


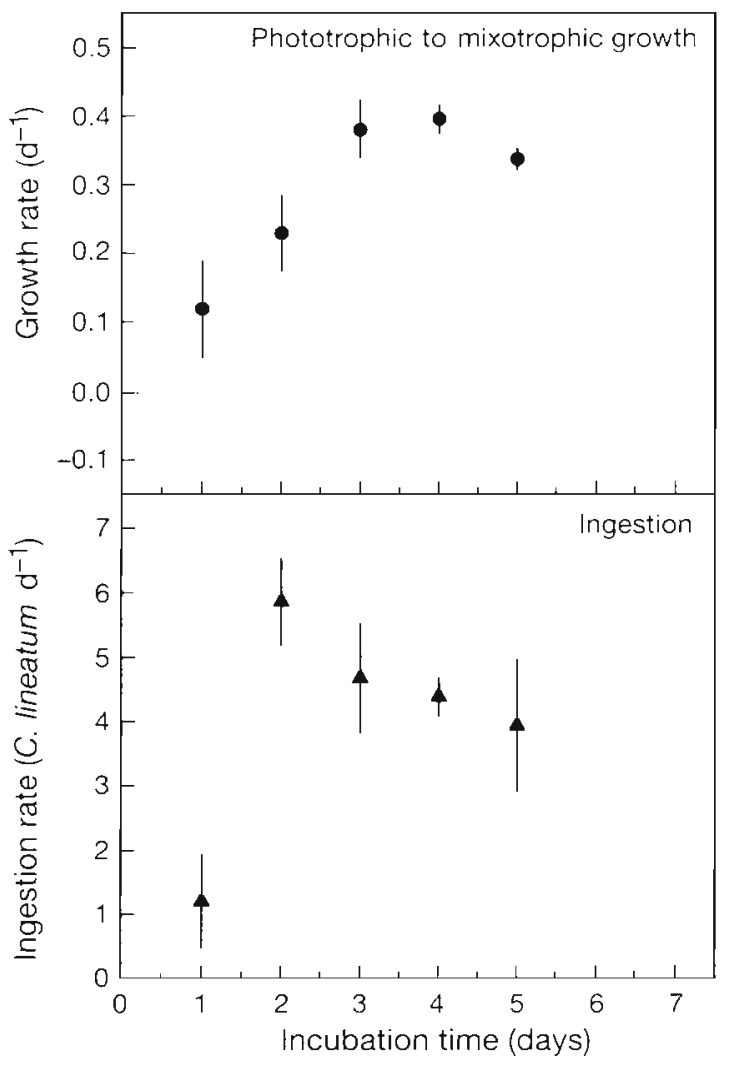

Fig. 6. Changes in mixotrophic growth rate (above) and per capita ingestion rate (below) of Fragilidium subglobosum fed with Ceratium lineatum $\left(-800\right.$ cells $\left.\mathrm{ml}^{-1}\right)$. F subglobosum was acclimated in phototrophic monocultures, kept in the light and fed at Day 0. Error bars indicate $\pm 1 \mathrm{SE}, \mathrm{n}=4$

basis of these results, it is evident that $F$. subglobosum is a facultative mixotroph which is capable of growing almost equally as well phototrophically as phagotrophically. Other facultative mixotrophs, e.g. the bacterivorous chrysomonads Ochromonas sp. (Andersson et al. 1989) and Poterioochromonas malhamensis (Sanders et al. 1990), are believed to be dependent primarily upon phagotrophy, since their phagotrophic $\mu_{\max }$ is much higher than their phototrophic $\mu_{\max }$. Compared with these species, $F$. subglobosum is thus remarkable in having only a relatively small difference between its independent phototrophic and phagotrophic $\mu_{\max }$.

Above $63 \mu \mathrm{E} \mathrm{m}^{-2} \mathrm{~s}^{-1}$. Fragilidium subglobosum is able to increase its ingestion rate in response to decreasing light intensities (Fig. 1), thereby acquiring more energy from phagotrophy when light intensity decreases. Such a relation has also been suggested in other mixotrophs (Bird \& Kalff 1989, Jones et al. 1993), but it has also been shown not to be a universal rule (Sanders et al. 1990, Veen 1991). In the haptophyte Chrysochromulina brevifilum (Jones et al. 1993), an inverse proportionality between food uptake and light intensity was found. In that work, however, the cultures were not acclimated to experimental light intensities prior to the experiment and the observed ingestion therefore represents an initial response to light conditions. These results are thus not directly comparable to data of studies based on acclimated cultures, as in this present work on F. subglobosum. At light intensities below $63 \mu \mathrm{E} \mathrm{m} \mathrm{m}^{-2} \mathrm{~s}^{-1}$, ingestion rates of $F$. subglobosum are relatively low, which is not consistent with the above suggested response to light intensities of above $63 \mu \mathrm{E} \mathrm{m}^{-2} \mathrm{~s}^{-1}$ Obviously, ingestion by F subglobosum is not merely a function of light intensity, but is more likely controlled by a combination of factors. It is possible that the digestive system of $F$. subglobosum is less efficient in conditions of poor light since in some mixotrophs light is even a necessity for maintaining phagotrophic activity (Caron et al. 1993, Keller et al. 1994).

Overall, mixotrophic growth rates of Fragilidium subglobosum are enhanced in comparison to purely phototrophic growth rates at corresponding light intensities (Fig. 1). This enhancement is particularly pronounced at low light intensities ( 0 to $\left.10 \mu \mathrm{E} \mathrm{m}^{-2} \mathrm{~s}^{-1}\right)$. whereas at intermediate light intensities (63 to $107 \mu \mathrm{E}$ $\left.\mathrm{m}^{-2} \mathrm{~s}^{1}\right)$, which are associated with maximum ingestion rates, enhancement of growth is relatively low. Assuming a phagotrophic yield of $41 \%$, photosynthesis must thus be depressed as a consequence of the high phagotrophic activity occurring at intermediate light intensities. The decrease in cellular chl a content in food-supplied cultures as compared with monocultures (Fig. 3) further supports this suggestion.

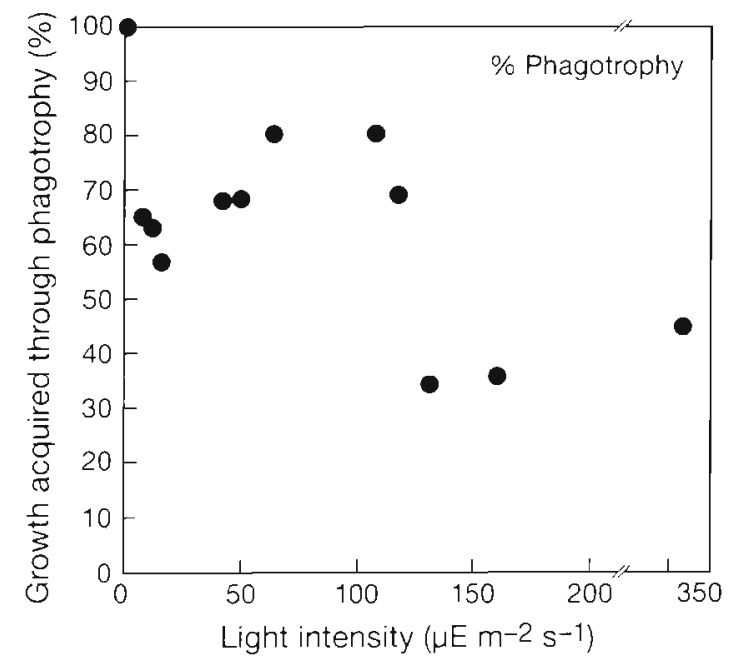

Fig. 7. Estimated percentage of Fragilidum subglobosum growth acquired through phagotrophy at various light intensities in food-satiated cultures; based on data from Fig. 3. A phagotrophic yield of $41 \%$, calculated on the basis of cultures growing in the dark, was applied to all light untensities 
Assuming a phagotrophic yield of $41 \%$, the estimated phagotrophic percentage of total mixotrophic growth as a function of light intensity (Fig. 7) shows that Fragilidium subglobosum acquires between 34 and $100 \%$ of its energy need from phagotrophy Highest dependence of phagotrophy exists in darkness and the lowest dependence exists at $I\left(\mu_{\max }\right)$ where photosynthesis must therefore be the main source of nutrition. This is in contrast to the cases of, e.g., Ochromonas sp. (Andersson et al. 1989) and Poterioochromonas malhamensis (Sanders et al. 1990), in that the growth of these species is dominated by phagotrophy (if food is abundant) regardless of light intensity.

The fact that food uptake by Fragilidium subglobosum was more pronounced in phagotrophically/ mixotrophically adapted cultures than in cultures which were not adapted to phagotrophy (Figs. 4, 5 \& 6) demonstrates that $F$. subglobosum needs about $24 \mathrm{~h}$ to adapt to phagotrophic metabolism. The physiological explanation for this is as yet unknown, but it may be speculated that cell functions involved in food uptake and/or digestion need time to develop after the cell has been growing purely phototrophically for some time.

The results presented in this work suggest that Fragilidium subglobosum has the potential of being an important grazer on Ceratium spp. in the planktonic food web. However, (probably) because F. subglobosum is difficult to identify in fixed samples reports of the species in the field are very rare (Skovgaard in press) and its significance as a grazer on Ceratium blooms can therefore not be estimated before more field investigations have been performed.

Acknowledgements. This paper constitutes part of my M.Sc thesis and I am grateful to my supervisor Per Juel Hansen for advice and constructive criticism throughout this study. I thank Tom Fenchel for critically reading the manuscript and for suggesting the ingestion rate calculations. I also thank. Bent Vismann for setting up the computer model and Catherine Bernard for fruitful discussions. I am indebted to Grete Moller Christensen for helping with cultivation of the organisms and to Leif Knudsen for technical assistance. This study was funded by the Danish National Science Foundation, contract no. 11-0420-1

This article was submitted to the editor

\section{LITERATURE CITED}

Andersson A, Falk S, Samuelsson G, Hagström $\AA$ (1989) Nutritional characteristics of a mixotrophic nanoflagellate, Ochromonas sp. Microb Ecol 17:251-262

Banse K (1982) Cell volumes, maximal growth rates of unicellular algae and ciliates, and the role of ciliates in the marine pelagial. Limnol Oceanogr 27:1059-1071

Bird DF, Kalff J (1989) Phagotrophic sustenance of a metalimnetic phytoplankton peak. Limnol Oceanogr 34:155-162

Caron DA, Sanders RW, Lim EL, Marrasé C, Amaral LA, Whitney S, Aoki RB, Porter KG (1993) Light-dependent phagotrophy in the freshwater mixotrophic chrysophyte Dinobryon cylindricum. Microb Ecol 25:93-111

Gaines G, Elbrächter M (1987) Heterotrophic nutrition. In: Taylor FJR (ed) The biology of dinoflagellates. Blackwell, Oxford, p 224-268

Hansen PJ (1989) The red tide dinoflagellate Alexandrium tamarense: effects on behaviour and growth of a tintinnid ciliate. Mar Ecol Prog Ser 53:105-116

Holen DA, Boraas ME (1995) Mixotrophy in chrysophytes. In: Sandgren CD, Smol JP, Kristiansen J (eds) Chrysophyte algae, ecology, phylogeny and development. Cambridge University Press, Cambridge, p 119-140

Jones HLJ, Leadbeater BSC, Green JC (1993) Mixotrophy in marine species of Chrysochromulina (Prymnesiophyceae) ingestion and digestion of a small green flagellate J Mar Biol Ass UK 73:283-296

Keller MD, Shapiro LP, Haugen EM, Cucci TL, Sherr EB, Sherr BF (1994) Phagotrophy of fluorescently labeled bacterla by an oceanic phytoplankter. Microb Ecol 28:39-52

Kimura B, Ishida Y (1985) Photophagotrophy in Uroglena americana, Chrysophyceae. Jpn J Limnol 46:315-318

Kimura B, Ishida Y (1989) Phospholipid as a growth factor of Uroglena americana, a red tide Chrysophyceae in Lake Biwa. Nippon Suisan Gakkaishi 55:799-804

Lorenzen, CJ (1967) Determination of chlorophyll and pheopigments: spectrophotometric equations. Limnol Oceanogr 12:343-36

Richardson K, Beardall J, Raven JA (1983) Adaptation of unicellular algae to irradiance: an analysis of strategies. New Phytol 93:157-191

Sanders RW, Porter KG (1988) Phagotrophic phytoflagellates. In: Marshall KC (ed) Advances in microbial ecology, vol 10. Plenum Press, New York, p 167-192

Sanders RW, Porter KG, Caron DA (1990) Relationship between phototrophy and phagotrophy in the mixotrophic chrysophyte Poterioochromonas malhamensis. Microb Ecol 19:97-109

Skovgaard A (in press) Engulfment of Ceratium spp. (Dinophyceae) by the thecate photosynthetic dinoflagellate Fragilidium subglobosum. Phycologia

Veen A (1991) Ecophysiological studies on the phagotrophic phytoflagellate Dinobryon divergens Imhof. PhD thesis, University of Amsterdam

Manuscript first received: May 10, 1996

Revised version accepted: September 3, 1996 